\title{
DESIGN, SYNTHESIS, AND EVALUATION OF NEW DERIVATIVE OF 1,2,4-TRIAZOLES FOR ANTIMICROBIAL AND ANTI-INFLAMMATORY ACTIVITY
}

\author{
PRABHU C. JALIHAL ${ }^{\mathrm{a}}$, VAIBHAV RAJORIYA ${ }^{\mathrm{b}}$, VARSHA KASHAW ${ }^{\mathrm{a}}$
}

aSVN Institute of Pharmaceutical Sciences, Swami Vivekananda University, Sagar, (M. P.), India, bDepartment of Pharmaceutical Sciences, Dr Harisingh Gour University (A Central University), Sagar, (M. P.) India

Email: varshakashaw@gmail.com

Received: 25 Jan 2018, Revised and Accepted: 15 Apr 2018

\begin{abstract}
Objective: The object of the study is to design, synthesize and biological evaluation of isoniazid derived 1,2,4-triazoles compounds.

Methods: Isoniazid based 1,2,4-triazoles derivatives have been synthesized by reaction of Isoniazid with carbon disulfide in basic medium (KOH) to form Potassium dithiocarbazinate salt and reaction with hydrazine hydrate converted into 4-amino-5-(pyridin-4-yl)-4H-1,2,4-triazole-3-thiol. These compounds were reacted with seven different benzaldehyde to form 4-[(substituted phenyl)-methylene]-amino-5-(pyridine-4-yl)-4H-1,2,4-triazol3-thiol (4). The final compounds were synthesized by reaction with four different acetanilide to form 4-[substituted phenyl)-methylene]-amino-3(N-substitutedcarboxamidomethylthio)-5-(pyridine-4-yl)-4H-1,2,4-triazoles derivatives. All these compounds were characterized by IR, ${ }^{1} \mathrm{H}-\mathrm{NMR}$, [13]C-NMR and elemental analysis. The antimicrobial activity was determined by the cup plate method. Acute anti-inflammatory activity determined by using carrageenan-induced rat paw edema model.
\end{abstract}

Results: Series PJ-A4, PJ-A7 and PJ-A13 showed more than 90\% of the zone of inhibition against both Gram positive and Gram negative organisms. The antifungal study suggested that among synthesized compounds series PJ-A4, A7, A9, A11 and A13 showed more than 90\% of zone of inhibition, A2, A10 and A12 shows more than $80 \%$ of the zone of inhibition. Anti-inflammatory study data indicate that compounds PJ-A4, PJ-A8, PJ-A9 and PJA13 produced 70 to $76 \%$ of paw edema inhibition compare to standard drug Ibuprofen which showed $83.3 \%$ after $5 \mathrm{~h}$.

Conclusion: Results suggested that the isoniazid based 1,2,4-triazole derivatives have significant antibacterial, antifungal and anti-inflammatory activity.

Keywords: 1,2,4-triazole, Zone of inhibition, Anti-inflammatory activity, Antimicrobial activity

(C) 2018 The Authors. Published by Innovare Academic Sciences Pvt Ltd. This is an open access article under the CC BY license (http://creativecommons.org/licenses/by/4.0/] DOI: http://dx.doi.org/10.22159/ijcpr.2018v10i4.28455

\section{INTRODUCTION}

Non-steroidal anti-inflammatory drugs (NSAIDs), primarily important for the treatment of inflammation and pain in arthritis. NSAIDs act by inhibiting PGs synthesis by blockage of enzyme cyclooxygenase-1. Two isoforms recognized as cyclooxygenase COX1 and COX-2. COX-1, is an isoform found in kidneys, GI tract, and platelets and used for hemostatic maintenance of the kidney and GI tract; but COX-2 is produced during injury. The drawback of NSAIDs is on long exposure causes the gastric ulcer, bleeding and renal disorder. This is most likely due to the presence of free carboxyl group on Non-steroidal anti-inflammatory drugs (NSAIDs) (Mishra et al. 2008). The GIT mucosal injury problems produced by NSAIDs are commonly believed to be caused by two different mechanisms. One is local irritation produced by free carboxylic acid group and inhibition of prostaglandin biosynthesis in the GIT.

Isoniazid is used as first-line treatment of tuberculosis and shown to be more effective as 1,2,4-triazoles derivatives to encounter inflammation, antibacterial and antimicrobial agents. This hurdle is to rectify by synthesis of the 1,2,4-triazoles derivatives that have more stable in structure. 1,2,4-triazoles has shown anti-tubercular, antimicrobial, hypoglycemic, anti-inflammatory, antibacterial, antifungal, anticancer, analgesic and antidepressant activities. A considerable amount of research activities are directed towards potent, more specific and less toxic anti-inflammatory agents and it offers a challenging task in the development of novel synthetic strategies.

In the current scenario, microbial resistance is one of the hurdles and needs the development of newer agent to target the diseases. Literature survey indicates that triazole, thiadiazole and triazine derivatives of Indomethacin have been synthesized and tested for antiinflammatory activity. The test compounds inhibited the induction of gastric mucosal lesions and their protective effects may be related to inhibition of lipid peroxidation in gastric mucosa. Prompted by these findings, it seemed of interest to synthesize new derivatives of 1,2,4triazole and investigate their anti-inflammatory activity.

The object of the current research is to synthesize new 1,2,4triazoles derivatives of isoniazid as potent antimicrobial and antiinflammatory agents. In continuation with the above researches we proposed to synthesized some triazole derivatives to design and synthesize new 1,2,4-triazoles derivatives 4-[substituted phenyl)methylene]-amino-3-(N-substituted-carboxamidmethylthio)-5(pyridine-4-yl)-4H-1,2,4-triazoles which were expected to show anti-microbial and anti-inflammatory properties. This paper discusses the most common and useful procedure for synthesizing 4-amino-3-mercapto-1,2,4-triazoles. In the present design, we synthesized newer di-substituted 1,2,4-triazoles derived from isonicotinic acid hydrazides (Isoniazid) by replacing a 4carbohydrazide group of isoniazid by substituting 1,2,4-triazole in a hope of getting a synergistic response of pyridine nucleus $(A)$ and 1,2,4-triazole nucleus (B) towards antibacterial, antifungal and antiinflammatory activity (fig. 1). Mannich base derivatives and triazole fused with 6-membered rings were reported to possess significant antitubercular activity. The two nitrogen atoms of the hydrazide group of the isoniazid are complementary to the two nitrogen atoms present at the 1 and 2 position of the triazole nucleus.

\section{MATERIALS AND METHODS}

Isoniazid (Isonicotinic acid hydrazides) was purchased from $\mathrm{CDH}$ (Chemical Drug House), India. Carbon-disulfide, potassium hydroxide, hydrazine hydrate, ethanol, methanol, glacial acetic acid, anhydrous ether, DMSO, aldehyde compounds (benzaldehyde, panisaldehyde, 4-bromobenzaldehyde, p-chlorobenzaldehyde, ptolualdehyde, p-nitrobenzaldehyde, Cinnamaldehyde) were 
purchased from the $\mathrm{CDH}$, New Delhi, India. and Alphachloroacetanilides compounds (2-chloro-2,6,-dimethylacetanilides, (4-chloroacetyl)-morpholine, 4-bromo-2,2'-dichloroacetanilides, 2chloro-N,N-diethylacetamides) were purchased from the Sigma Aldrich, New Delhi, India. The chemical used for experimental work were synthetic grade. The melting points of the synthesized compounds were determined in open glass capillaries. IR spectra were recorded on ALPHA (Bruker) FTIR Spectrometer. Elemental analysis was performed and found values were within $0.4 \%$ of theoretical values. $1 \mathrm{H}$ NMR and ${ }^{13} \mathrm{C}$ NMR spectra were recorded on Bruker Avance 400 spectrophotometer at $400 \mathrm{MHz}, 5 \mathrm{~mm}$ multinuclear inverse probe head, low and high-temperature facility and HRMAS accessory. Mass Spectra were recorded using Mass Spectrometers Jeol SX-102 (FAB) by ESI.
B<smiles>NC(=O)c1ccncc1</smiles>

(a)

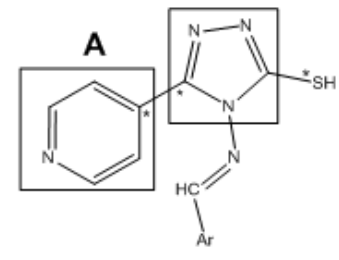

(b)
B

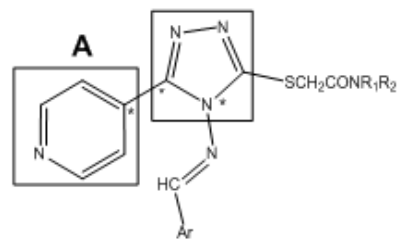

(c)

Fig. 1: Proposed pictorial representation of the proposed hypothesis. a) Chemical structure of the Isoniazid b) and c) are proposed compounds scheme for the designing of the 1,2,4-triazole compounds

\section{Synthesis of potassium dithiocarbazinate salt}

Isonicotinic acid hydrazide (0.10 mol) [1] was reacted with an ethanolic solution of potassium hydroxide $(0.15 \mathrm{~mol})$ along with carbon disulfide $(0.15 \mathrm{~mol})$ was added slowly to it. The reaction mixture was diluted with absolute ethanol (50 ml) and stirred continuously for $16 \mathrm{~h}$ at room temperature on a magnetic stirrer. The precipitated potassium dithiocarbazinate salt was collected by filtration, washed with anhydrous ether and dried. The potassium dithiocarbazinate salt [2] thus obtained was used in the next step without further purification.

\section{Synthesis of 4-amino-5-(pyridin-4-yl)-4H-1,2,4-triazole-3-thiol}

Potassium dithiocarbazinate salt (2) (0.079 mol) reacted with aqueous hydrazine hydrate $(12 \mathrm{ml}, 0.24 \mathrm{~mol})$ solution and refluxed for $4 \mathrm{~h}$, hydrogen sulfide ( $\mathrm{H} 2 \mathrm{~S}$ gas) was evolved during the reaction was observed and indicated by the lead acetate solution (confirmatory testturn lead acetate soaked filter paper convert white to black). The reaction mixture was cooled to room temperature, diluted with ice-cold distilled water and subsequent acidification with dilute acetic acid. Obtained light yellow precipitate was filtered, washed with cold distilled water and dried. Recrystallization was done using absolute ethanol to get white crystals [3]. The compound 3 exist in thione-thiol tautomeric forms, but our investigation showed that in this case, the thiol str. ucture dominated in the solid state, as indicated by the IR and NMR data of the compound. Yield: 78\%, m. p.: $214-216^{\circ} \mathrm{C}$; IR (cm-1): 3160 (N-H), 3000 (C-H), $2582(\mathrm{~S}-\mathrm{H}), 1608(\mathrm{C}=\mathrm{N}), 1571(\mathrm{C}=\mathrm{C}), 709$ (out of plane $\mathrm{C}-\mathrm{H}$ bending), 689 (C-S). 1H NMR (ppm): 3.77 (s,1H,-NH2), 10.51 (Aromatic C-SH), 7.92 (d, 1H, Benzylidenimin), 8.59 (d, 1H, beta-pyridyl); 13C NMR (ppm): 151.1 (1,2,4-triazoles), 134.0 (C1-pyridine), 121.3 (C2 and C6pyridine). 149.8 (C3 and C5-pyridine), LC-MS m/z: 193.23.

Synthesis of 4-[(substituted phenyl)-methylene]-amino-5(pyridine-4-yl)-4H-1,2,4-triazol-3-thiol (4a-4g)

To a suspension of corresponding compound 1,2,4-triazole-3-thiol (3) $(0.005 \mathrm{~mol})$ in methanol $(50 \mathrm{ml})$ and an equimolar quantity of aromatic aldehyde in methanol $(20 \mathrm{ml})$ was mixed. This suspension was heated until a clear solution was obtained and refluxed for $3 \mathrm{~h}$ in the presence of a few drops of concentrated hydrochloric acid in a water bath. The reaction solution was left undisturbed overnight. On the next day, the separated solid were filtered, washed with ethanol and recrystallized from ethanol to procure the product/compound [4].

Synthesis of 4-[substituted phenyl)-methylene]-amino-3-(Nsubstituted-carboxamidmethyl thio)-5-(pyridine-4-yl)-4H-1,2,4triazoles

Compound 1,2,4-triazol-3-thiol [4] $(0.01 \mathrm{~mol})$ was dissolved in aqueous potassium hydroxide solution $(0.61 \mathrm{~g}$ in $100 \mathrm{ml}$ distilled water) with stirring till a clear yellow color solution was obtained. It was filtered to remove any suspended impurities. Then various $\mathrm{N}$ substituted- $\alpha$-chloroacetanilides $(0.01 \mathrm{~mol})$ compound were dissolved in ethanol and added with shaking at $55{ }^{\circ} \mathrm{C}$ stirrered for $4.5 \mathrm{~h}$. Then the reaction mixture was left overnight and the next day, the separated solid was filtered and washed twice with cold distilled water to remove $\mathrm{KCl}$, dried and recrystallized from dilute glacial acetic acid [5]. In the case of aliphatic $\mathrm{N}$-substituted- $\alpha$-chloroacetanilides, the amide was added at room temperature.

PJ-A1: 2,4-(benzylideneamino)-5-(pyridin-4-yl)-4H-1,2,4-triazol3-yl)thio)-N-(2,6-dimethyl phenyl)acetamide

Molecular formula: $\mathrm{C}_{24} \mathrm{H}_{22} \mathrm{~N}_{6} \mathrm{OS}$; Molecular weight: 442.54; TLC (Rf value): 0.62; IR (cm-1, KBr): 3231(-NH Str.); 3144 (C-H str.); 3028 (C-H str.); 1642.2 (CONH str.); 1396 (SCH2 str.); 1607.7 (C=N str.); 1439 (C-H def.); 1450 (C-C str.); 1650 (C=C str.); 1317 (C-N str.); 1530 (C=N str.); 688 (C-S str.); 1H NMR (DMSO-d6, $\delta$ ppm): 9.85 ($\mathrm{N}=\mathrm{CH}) ; 9.04(\mathrm{NH}) ; 8.89-8.83(-\mathrm{C} 5 \mathrm{H} 4 \mathrm{~N}) ; 8.79-8.76(-\mathrm{C} 5 \mathrm{H} 4 \mathrm{~N}) ; 7.99$ 7.97 (-C6H4); 7.93-7.88 (-C6H4); 4.42 (SCH2); 2.21-2.24 ((CH3)2; ${ }^{13} \mathrm{C}$ NMR (DMSO-d6, $\left.\delta \mathrm{ppm}\right): 154.3(\mathrm{~N}=\mathrm{CH}) ; 169.2(\mathrm{C}=\mathrm{O}$ of NH2); 137.1 (C1 of 2,6-dimethylphenyl ring); 130.7 (C2 and C6 of 2,6dimethylphenyl ring); 127.7 (C3 and C5 of 2,6-dimethylphenyl ring); 121.3 (C2 of pyridine); 149.8 (C3 and C5 of pyridine ring: 134.0 (C6 of pyridine ring); 150 (C3 of 1,2,4-triazole ring); 159 (C5 of 1,2,4triazole ring); 132.3 (C1 of benzene ring); 129.2 (C2 and C6 of benzene ring); 128.8 ( $\mathrm{C} 3$ and $\mathrm{C} 5$ of benzene ring); 131.0 (C4 of benzene ring); 38.5 (SCH2);. MASS (m/z): 442.158

PJ-A2: 2,4-(2-chlorobenzylidene)amino)-5-(pyridin-4-yl)-4H1,2,4-triazol-3-yl)thio)-N-(2,6-dimethylphenyl)acetamide

Molecular formula: $\mathrm{C}_{24} \mathrm{H}_{21} \mathrm{ClN}_{6} \mathrm{OS}$; Molecular weight: 476.94; TLC $\left(\mathrm{R}_{f}\right.$ value): 0.65; IR (cm-1, KBr): 3213 (-N-H Str.); 3109 (C-H str.); 3033 (C-H str.); 1646 (CONH str.); 1396 (SCH2 str.); 1609 (C=N str.); 1430 (C-H def.); 1450 (C-C str.); 1650 (C=C str); 1317 (C-N str.); 1540 (C=N str.); 688 (C-S str.); 754.2 (C-Cl str.); 1H NMR (DMSO-d6, $\delta$ ppm): 9.85 ($\mathrm{N}=\mathrm{CH}) ; 9.0(\mathrm{NH}) ; 4.38$ (SCH2); 2.20-2.24 ((CH3)2; ${ }^{13} \mathrm{C}$ NMR (DMSO-d6, $\delta$ ppm): $156(\mathrm{~N}=\mathrm{CH}) ; 170$ ( $\mathrm{C}=\mathrm{O}$ of amide); 137 ( $\mathrm{C} 1$ of 2,6-dimethylphenyl ring); 131 ( $\mathrm{C} 2$ and $\mathrm{C} 6$ of 2,6-dimethylphenyl ring); 125 (C3 and C5 of 2,6dimethyl phenyl ring); 135 (C6 of pyridine ring); 121 (C2 of pyridine ring pyridine); 148 ( $\mathrm{C} 3$ and $\mathrm{C} 5$ of pyridine ring); 150 (C2 of 1,2,4-triazole ring); 159 (C5 of 1,2,4-triazole ring); 130.4 (C1 of benzene ring); 130.2 (C2 and C6 of benzene ring); 128.6 (C3 and C5 of benzene ring); 136.0 (C4 of benzene ring); 38.5 (SCH2); 16.9 (CH3 of 2,6 dimethyl phenyl) Mass (m/z): 476

PJ-A3: 2,4-(3-chlorobenzylidene)amino)-5-(pyridin-4-yl)-4H1,2,4-triazol-3-yl)thio)-N-(2,6-dimethylphenyl)acetamide

Molecular formula: C24H21CIN6OS; Molecular weight: 476.94; TLC (Rf value): 0.68; Elemental Analysis: Nitrogen \% (Found/Calc.)17.62 
(17.60); Sulphur \% (Found/Calc.) 6.68 (6.69); IR (cm-1, KBr): 3213(-NH Str.); 3109 (C-H str.); 3033(C-H str.); 1646 (CONH str.); 1396 ( $\mathrm{SCH}_{2}$ str.); 1609 (C=N str.); 1430 (C-H def.); 1450(C-C str.); 1650 (C=C str.); 1317 (C-N str.); 1540 (C=N str.); 688 (C-S str.); 754.2(C-Cl str.) 1H NMR (DMSO-d6, $\delta$ ppm): $9.85(-\mathrm{N}=\mathrm{CH}) ; 9.01(\mathrm{~N}-\mathrm{H})$; 7.65-8.9 aromatic protons; 4.38 (SCH2); 2.20-2.24 (CH3)2; ${ }^{13} \mathrm{C}$ NMR (DMSO-d6, $\delta$ ppm): $156(\mathrm{~N}=\mathrm{CH}) ; 170$ (C=0 of amide); 137 (C1 of 2,6dimethylphenyl ring); 131 (C2 and C6 of 2,6-dimethylphenyl ring); 125 (C3 and C5 of 2,6-dimethylphenyl ring); 135 (C6 of pyridine ring); 121 (C2 of pyridine ring pyridine); 148 (C3 and C5 of pyridine ring); 150 (C2 of 1,2,4-triazole ring); 159 (C5 of 1,2,4-triazole ring); 130.4 (C1 of benzene ring); 130.2 (C2 and C6 of benzene ring); 128.6 (C3 and C5 of benzene ring); 136.0 (C4 of benzene ring); 38.5 (SCH2); 16.9 (CH3 of 2,6 dimethyl phenyl); Mass (m/z): 476.

\section{PJ-A4: 2,4-(4-chlorobenzylidene)amino)-5-(pyridin-4-yl)-4H-} 1,2,4-triazol-3-yl)thio)-N-(2,6-dimethylphenyl)acetamide

Molecular formula: C24H21CIN6OS; Molecular weight: 476.94, TLC (Rf value): 0.65 IR (cm-1, KBr): 3213-N-H Str.; 3109 C-H str.; 3033 CH str.; 1646 CONH str.; 1396 SCH2 str. 1609 C=N str.; 1430 C-H def; 1450 C-C str.; 1650 C=C str.; 1317 C-N str.; $1540 \mathrm{C}=\mathrm{N}$ str.; $688 \mathrm{C}-\mathrm{S}$ str.; 754.2 C-Cl str.; 1H NMR (DMSO-d6, $\delta$ ppm): $9.85(-\mathrm{N}=\mathrm{CH}) ; 9.0(-$ $\mathrm{NH}$ ); 7.65-8.9 (aromatic protons); 4.38 (SCH2) 2.20-2.24 (CH3)2; ${ }^{13} \mathrm{C}$ NMR (DMSO-d6, $\delta \mathrm{ppm}$ ): $156 \mathrm{~N}=\mathrm{CH} ; 170 \mathrm{C}=0$ of amide; $137 \mathrm{C} 1$ of 2,6-dimethylphenyl ring; $131 \mathrm{C} 2$ and $\mathrm{C} 6$ of 2,6-dimethylphenyl ring; $125 \mathrm{C} 3$ and $\mathrm{C} 5$ of 2,6-dimethylphenyl ring; $135 \mathrm{C} 1$ of pyridine ring; $121 \mathrm{C} 2$ of pyridine ring pyridine; $148 \mathrm{C} 3$ and $\mathrm{C} 5$ of pyridine ring; 150 C2 of 1,2,4-triazole ring; 159 C5 of 1,2,4-triazole ring; 130.4 C1 of benzene ring; $130.2 \mathrm{C} 2$ and $\mathrm{C} 6$ of benzene ring; $128.6 \mathrm{C} 3$ and $\mathrm{C} 5$ of benzene ring; $136.0 \mathrm{C} 4$ of benzene ring; $38.5 \mathrm{SCH} 2$; $16.9 \mathrm{CH} 3$ of 2,6 dimethyl phenyl. MASS (m/z): 476.

\section{PJ-A5:2,4-((2-bromobenzylidene)amino)-5-(pyridin-4-yl)-4H-}

\section{1,2,4-triazol-3-yl)thio)-N(2,6-dimethyl phenyl)acetamide}

Molecular formula: C24H21BrN6OS; Molecular weight: 520.06: TLC (Rf value): 0.74; IR (cm-1, KBr): 3210-N-H Str.; 3120C-H str.; 3030CH; 1640 CONH str.; 1390 SCH2 str.; 1603 C=N str.; 1433; C-H def.; 1452C-C str.; 1653 C=C str.; 1317 C-N str.; $1600 \mathrm{C}=\mathrm{N}$ str.; $680 \mathrm{C}-\mathrm{S}$ str.; C-Br str.; 1H NMR (DMSO-d6, $\delta$ ppm): $9.80(-\mathrm{N}=\mathrm{CH}) ; 9.04(-\mathrm{NH})$; 7.65-8.82 (aromatic protons); 4.42 (SCH2); $2.20-2.23$ (CH3)2; ${ }^{13} \mathrm{C}$ NMR (DMSO-d6, $\delta$ ppm): 151.3; $\mathrm{N}=\mathrm{CH} ; 168.2 \mathrm{C}=0$ of amide; $137.2 \mathrm{C} 1$ of 2,6-dimethylphenyl ring; $130.7 \mathrm{C} 2$ and $\mathrm{C} 6$ of 2,6-dimethylphenyl ring; $127.2 \mathrm{C} 3$ and $\mathrm{C} 5$ of 2,6-dimethylphenyl ring; $134 \mathrm{C} 1$ of pyridine ring; $121.3 \mathrm{C} 2$ of pyridine ring pyridine; $149.8 \mathrm{C} 3$ and C5 of pyridine ring; $150.2 \mathrm{C} 2$ of 1,2,4-triazole ring; $158 \mathrm{C} 5$ of 1,2,4-triazole ring; 131.4 C1 of benzene ring; $128.6 \mathrm{C} 2$ and $\mathrm{C} 6$ of benzene ring; $131.8 \mathrm{C} 3$ and $\mathrm{C} 5$ of benzene ring; $125.4 \mathrm{C} 4$ of benzene ring; $40.2 \mathrm{SCH} 2 ; 17.9$ CH3 of 2,6 dimethyl phenyl. MASS (m/z): 520.06.

PJ-A6: 2,4-(3-bromobenzylideneamino)-5-(pyridin-4-yl)-4H1,2,4-triazol-3-yl)thio)- $\mathrm{N}$-(2,6-dimethylphenyl) acetamide

Molecular formula: C24H21BrN6OS; Molecular weight: 476.94; TLC (Rf value): 0.67; IR (cm-1, KBr): 3210-N-H Str.; 3120 C-H str.; 3030 CH; 1640 CONH str.; 1390 SCH2 str.; 1603 C=N str.; 1433 C-H def.; 1452 C-C str.; 1653 C=C str.; 1317 C-N str.; 1600 C=N str.; 680 C-S str.; 720 C-Br str.; 1H NMR (DMSO-d6, $\delta$ ppm): $9.80(-\mathrm{N}=\mathrm{CH}) ; 9.04(-\mathrm{NH}) ; 7.65-$ 8.82 (aromatic protons); 4.42 (SCH2); $2.20-2.23$ (CH3)2. ${ }^{13} \mathrm{C}$ NMR (DMSO-d6, $\delta$ ppm): $151.3 \mathrm{~N}=\mathrm{CH}$; $168.2 \mathrm{C}=\mathrm{O}$ of amide; $137.2 \mathrm{C} 1$ of 2,6dimethylphenyl ring; $130.7 \mathrm{C} 2$ and $\mathrm{C} 6$ of 2,6-dimethylphenyl ring; 127.2 C3 and C5 of 2,6-dimethylphenyl ring; $134 \mathrm{C} 1$ of pyridine ring; $121.3 \mathrm{C} 2$ of pyridine ring pyridine; $149.8 \mathrm{C} 3$ and C5 of pyridine ring; 150.2 C2 of 1,2,4-triazole ring; 158 C5 of 1,2,4-triazole ring; 131.4 C1 of benzene ring; $128.6 \mathrm{C} 2$ and C6 of benzene ring; $131.8 \mathrm{C} 3$ and $\mathrm{C} 5$ of benzene ring; $125.4 \mathrm{C} 4$ of benzene ring; $40.2 \mathrm{SCH} 2 ; 17.9 \mathrm{CH} 3$ of 2,6 dimethyl phenyl. MASS (m/z): 520.06 .

PJ-A7: 2,4-(4-methylbenzylideneamino)-5-(pyridin-4-yl)-4H1,2,4-triazol-3-yl)thio)-N-(2,6-dimethylphenyl) acetamide

Molecular formula: C25H24N6OS; Molecular weight: 456; TLC (Rf value): 0.71; IR (cm-1, KBr): 3209-N-H Str.; 3125C-H str.; 3034C-H; 1647 CONH str. 1394 SCH2 str. $1608 \mathrm{C}=\mathrm{N}$ str. $1430 \mathrm{C}-\mathrm{H}$ def; $1450 \mathrm{C}-\mathrm{C}$ str. $1653 \mathrm{C}=\mathrm{C}$ str. $1317 \mathrm{C}-\mathrm{N}$ str. $1600 \mathrm{C}=\mathrm{N}$ str. $680 \mathrm{C}-\mathrm{S}$ str.; $1 \mathrm{H}$ NMR (DMSO-d6, $\delta$ ppm): $9.32(-\mathrm{N}=\mathrm{CH}) ; 9.08(-\mathrm{NH}) ; 7.69-8.79$ (aromatic protons); 4.42 (SCH2); 2.21-2.24 (CH3)2; ${ }^{13} \mathrm{C}$ NMR (DMSO-d6, $\delta$ ppm) $154.3 \mathrm{~N}=\mathrm{CH} ; 170.2 \mathrm{C}=0$ of amide; $137.1 \mathrm{C} 1$ of 2,6-dimethylphenyl ring; 130.7 C2 and C6 of 2,6-dimethylphenyl ring; 127.5 C3 and C5 of 2,6dimethylphenyl ring; $134 \mathrm{C} 1$ of pyridine ring; $121.3 \mathrm{C} 2$ of pyridine; 149.9 C3 and C5 of pyridine ring; 150.2 C2 of 1,2,4-triazole ring; 159 C5 of 1,2,4-triazole ring; 131.4 C1 of benzene ring; $128.6 \mathrm{C} 2$ and C6 of benzene ring; $131.8 \mathrm{C} 3$ and $\mathrm{C} 5$ of benzene ring; $140.4 \mathrm{C} 4$ of benzene ring; $40.5 \mathrm{SCH} 2 ; 18 \mathrm{CH} 3$ of 2,6 dimethyl phenyl. MASS (m/z): 456.17 .

PJ-A8: 2,4-(4-methoxybenzylideneamino)-5-(pyridin-4-yl)-4H1,2,4-triazol-3-yl)thio)-N-(2,6-dimethyl phenyl) acetamide

Molecular formula: C25H24N6O2S; Molecular weight: 472.56; TLC (Rf value): 0.56; IR (cm-1, KBr): 3215-N-H Str.; 3108 C-H str.; 3027 C-H str; 1620 CONH str.; 1392 SCH2 str.; 1603 C=N str.; $1430 \mathrm{C}-\mathrm{H}$ def.; 1454 C-C str.: 1652 C=C str. $1318 \mathrm{C}-\mathrm{N}$ str. $1532 \mathrm{C}=\mathrm{N}$ str. $685 \mathrm{C}-\mathrm{S}$ str. 1H NMR (DMSO-d6, $\delta$ ppm): $9.82-\mathrm{N}=\mathrm{CH} ; 9.04 \mathrm{NH}$; 7.63-8.89 aromatic protons; $4.40 \mathrm{SCH} 2 ; 3.24 \mathrm{OCH} 3 ; 2.2-2.3(\mathrm{CH} 3) 2 .{ }^{13} \mathrm{C}$ NMR (DMSO-d6, $\delta$ ppm): $154.3 \mathrm{~N}=\mathrm{H} ; 169.2 \mathrm{C}=0$ of amide; $137.1 \mathrm{C} 1$ of 2,6dimethylphenyl ring; $130.7 \mathrm{C} 2$ and $\mathrm{C} 6$ of 2,6-dimethylphenyl ring 127.2 C3 and C5 of 2,6-dimethylphenyl ring; $134 \mathrm{C} 1$ of pyridine ring; $120.3 \mathrm{C} 2$ of pyridine ring pyridine; $148.9 \mathrm{C} 3$ and C5 of pyridine ring; 151.2 C2 of 1,2,4-triazole ring; 159 C5 of 1,2,4-triazole ring; 131.4 C1 of benzene ring; $124.6 \mathrm{C} 2$ and $\mathrm{C} 6$ of benzene ring; $130.2 \mathrm{C} 3$ and $\mathrm{C} 5$ of benzene ring; $165.4 \mathrm{C} 4$ of benzene ring; $41.5 \mathrm{SCH} 2 ; 17.9 \mathrm{CH} 3$ of 2,6 dimethyl phenyl; 55.8 OCH3; Mass (m/z): 472.56 .

PJ-A9: 2,4-(2,4-dichlorobenzylideneamino)-5-(pyridin-4-yl)4H-1,2,4-triazol-3-yl)thio)-N-(2,6-dimethylphenyl) acetamide

Molecular formula: C24H20Cl2N6OS; Molecular weight: 511.0; TLC (Rf value): 0.49; IR (cm-1, KBr): 3210-N-H Str.;3035 C-H str.; 3027 CH str.; 1680 CONH str.; 1390 SCH2 str.; $1610 \mathrm{C}=\mathrm{N}$ str.; $1430 \mathrm{C}-\mathrm{H}$ def.; 1458 C-C str.; 1656 C=C str.; 1320 C-N str.; 1538 C=N str.; 685 C-S str.; $870.4 \mathrm{~cm}-1 \mathrm{C}-\mathrm{Cl}$ str.; $1 \mathrm{H}$ NMR (DMSO-d6, $\delta \mathrm{ppm}$ ): $10.22-\mathrm{N}=\mathrm{CH}_{\text {; }}$ $8.09 \mathrm{NH}$; 7. 3-8.2 aromatic protons; $4.40 \mathrm{SCH} 2 ; 2.0-2.12(\mathrm{CH} 3) 2 .{ }^{13} \mathrm{C}$ NMR (DMSO-d6, $\delta$ ppm):150.3 N=CH; $173.2 \mathrm{C}=0$ of amide; $130.1 \mathrm{C} 1$ of 2,6-dimethylphenyl ring; $128.7 \mathrm{C} 2$ and C6 of 2,6-dimethylphenyl ring; $125.2 \mathrm{C} 3$ and C5 of 2,6-dimethylphenyl ring; $130 \mathrm{C} 1$ of pyridine ring; $120.3 \mathrm{C} 2$ of pyridine ring pyridine; $140.9 \mathrm{C} 3$ and $\mathrm{C} 5$ of pyridine ring; $147.2 \mathrm{C} 2$ of 1,2,4-triazole ring; $155 \mathrm{C} 5$ of 1,2,4-triazole ring; 125.4 C1 of benzene ring; $126.6 \mathrm{C} 2$ and $\mathrm{C} 6$ of benzene ring; $122.2 \mathrm{C} 3$ and $\mathrm{C} 5$ of benzene ring; $138.4 \mathrm{C} 4$ of benzene ring; $35.5 \mathrm{SCH} 2 ; 20.3$ CH3 of 2,6 dimethyl phenyl. MASS (m/z): 511.06 .

PJ-A10: 2,4-(2,6-dichlorobenzylideneamino)-5-(pyridin-4-yl)4H-1,2,4-triazol-3-yl)thio)-N-(2,6-dimethylphenyl) acetamide

Molecular formula: C24H20Cl2N6OS; Molecular weight: 511.0; TLC (Rf value): 0.48; IR (cm-1, KBr): 3218-N-H Str.; 3038 C-H str.; 3020 C-H str.; 1682 CONH str.; 1394 SCH2 str.; 1612 C=N str.; 1432 C-H def.; 1458 C-C str.; 1656 C=C str.; 1320 C-N str.; 1538 C=N str.; 685 C-S str.; $870 \mathrm{C}-\mathrm{Cl}$ str.; $1 \mathrm{H}$ NMR (DMSO-d6, $\delta$ ppm): $10.3-\mathrm{N}=\mathrm{CH}$; 8.19 $\mathrm{NH}$; 7. 3-8.6 aromatic protons; 4.42 SCH2; 2.0-2.12 (CH3)2. ${ }^{13} \mathrm{C}$ NMR (DMSO-d6, $\delta \mathrm{ppm}$ ): $150.3 \mathrm{~N}=\mathrm{CH} ; 172.2 \mathrm{C}=0$ of amide; $130.1 \mathrm{C} 1$ of 2,6-dimethylphenyl ring; $128.7 \mathrm{C} 2$ and $\mathrm{C} 6$ of 2,6-dimethylphenyl ring; 125.2 C3 and C5 of 2,6-dimethylphenyl ring; $130 \mathrm{C} 1$ of pyridine ring; $121.3 \mathrm{C} 2$ of pyridine ring pyridine; $140.9 \mathrm{C} 3$ and $\mathrm{C} 5$ of pyridine ring; $147.2 \mathrm{C} 2$ of 1,2,4-triazole ring; $155 \mathrm{C} 5$ of 1,2,4-triazole ring; $125 \mathrm{C} 1$ of benzene ring; $126 \mathrm{C} 2$ and $\mathrm{C} 6$ of benzene ring; $122.2 \mathrm{C} 3$ and C5 of benzene ring; 138.4 C4 of benzene ring; 35.5 SCH2; 20.3 CH3 of 2,6 dimethyl phenyl. MASS (m/z): 511.06 .

PJ-A11:2,4-(4-N; Ndimethylamino-benzylidene) amino)-5(pyridin-4-yl)-4H-1,2,4-triazol-3-yl)thio)-N-(2,6-dimethylphenyl)acetamide

Molecular formula: C26H28N7OS; Molecular weight: 486; TLC (Rf value): 0.72; IR (cm-1, KBr): 3350-N-H Str.; $3108 \mathrm{C}-\mathrm{H}$ str.; $3068 \mathrm{C}-\mathrm{H}$ str.; 1672 CONH str.; 1480 SCH2 str.; $1612 \mathrm{C}=\mathrm{N}$ str.; $1439 \mathrm{C}-\mathrm{H}$ def.; 1478 C-C str.; 1658 C=C str.;1340 C-N str.; $1588 \mathrm{C}=\mathrm{N}$ str.; $695 \mathrm{C}-\mathrm{S}$ str.; $1 \mathrm{H}$ NMR (DMSO-d6, $\delta \mathrm{ppm}$ ): $8.3-\mathrm{N}=\mathrm{CH} ; 8.10 \mathrm{NH}$; $6.8-8.9$ aromatic protons; $3.82 \mathrm{SCH} 2 ; 3.22 \mathrm{~N}(\mathrm{CH} 3) 2 ; 2.3-2.32(\mathrm{CH} 3) 2 .{ }^{13} \mathrm{C}$ NMR (DMSO-d6, $\delta \mathrm{ppm}$ ): $158.3 \mathrm{~N}=\mathrm{CH} ; 172.2 \mathrm{C}=0$ of amide; $138.1 \mathrm{C} 1$ of 2,6-dimethylphenyl ring; $128.7 \mathrm{C} 2$ and $\mathrm{C} 6$ of 2,6-dimethylphenyl ring; $132.2 \mathrm{C} 3$ and $\mathrm{C} 5$ of 2,6-dimethylphenyl ring; $135 \mathrm{C} 1$ of pyridine ring; $120.3 \mathrm{C} 2$ of pyridine ring; $150.9 \mathrm{C} 3$ and $\mathrm{C} 5$ of pyridine ring; 
148.2 C2 of 1,2,4-triazole ring; 149 C5 of 1,2,4-triazole ring; 125 C1 of benzene ring; $130 \mathrm{C} 2$ and $\mathrm{C} 6$ of benzene ring; $118.2 \mathrm{C} 3$ and $\mathrm{C} 5$ of benzene ring; $152.4 \mathrm{C} 4$ of benzene ring; $35.5 \mathrm{SCH} 2 ; 42.5 \mathrm{~N}-\mathrm{CH} 3 ; 26.3$ CH3 of 2,6 dimethyl phenyl; MASS (m/z): 486.02.

J-A12:2,4-(4-Fluoroaminobenzylidene)amino)-5-(pyridin-4-yl)4H-1,2,4-triazol-3-yl)thio)-N-(2,6-dimethyl phenyl)acetamide

Molecular formula: C24H22 FN60S; Molecular weight: 462; TLC (Rf value): 0.70. IR (cm-1, KBr): 3150-N-H Str.; 3028 C-H str.; 2948 C-H str.; 1672 CONH str.; 1380 SCH2 str.; 1582 C=N str.; 1430 C-H def; 1478 C-C str.; 1650 C=C str.; 1380 C-N str.; 1580 C=N str.; 695 C-S str.; 978 C-F Str.; 1H NMR (DMSO-d6, $\delta$ ppm): 9.3-N=CH; $8.09 \mathrm{NH}$; 6.8-8.65 aromatic protons; $4.2 \mathrm{SCH} 2 ; 2.0-2.12(\mathrm{CH} 3) 2 ;{ }^{13} \mathrm{C} \mathrm{NMR}$ (DMSO-d6, $\delta \mathrm{ppm}$ ): $160.3 \mathrm{~N}=\mathrm{CH} ; 168.2 \mathrm{C}=0$ of amide; $132.1 \mathrm{C} 1$ of 2,6-dimethylphenyl ring $125.7 \mathrm{C} 2$ and C6 of 2,6-dimethylphenyl ring; $122.2 \mathrm{C} 3$ and $\mathrm{C} 5$ of 2,6-dimethylphenyl ring; $136 \mathrm{C} 1$ of pyridine ring; $121.3 \mathrm{C} 2$ of pyridine ring pyridine; $152.9 \mathrm{C} 3$ and $\mathrm{C} 5$ of pyridine ring; $146.2 \mathrm{C} 2$ of 1,2,4-triazole ring; $150 \mathrm{C} 5$ of 1,2,4-triazole ring; $128 \mathrm{C} 1$ of benzene ring; $132 \mathrm{C} 2$ and $\mathrm{C} 6$ of benzene ring; $115.2 \mathrm{C} 3$ and C5 of benzene ring; 168.4 C4 of benzene ring; 35.5 SCH2; $25.6 \mathrm{CH} 3$ of 2,6 dimethyl phenyl. MASS (m/z): 462.02.

PJ-A13: 2,4-(3-Hydroxybenzylidene)amino)-5-(pyridin-4-yl)4H-1,2,4-triazol-3-yl)thio)-N-(2,6-dimethylphenyl)acetamide

Molecular formula: C24H23N60S; Molecular weight: 459; TLC (Rf value): 0.69; IR (cm-1, KBr): 3420 O-H, Str.; 3350-N-H Str.; 3008 C-H str.; 2980 C-H str.; 1668 CONH str.; 1420 SCH2 str.;1580 C=N str.; 1430 C-H def.; 1470 C-C str.; 1650 C=C str.; 1380 C-N str.; $1580 \mathrm{C}=\mathrm{N}$ str.; 685 C-S str.; $1 \mathrm{H}$ NMR (DMSO-d6, $\delta$ ppm): 7.89-N=CH; $8.90 \mathrm{NH}$; 7.8-8.9 aromatic protons; 4.0 SCH2; $3.87 \mathrm{O}-\mathrm{H}$; 2.35-2.37 (CH3)2. ${ }^{13} \mathrm{C}$ NMR (DMSO-d6, $\delta$ ppm): $158.3 \mathrm{~N}=\mathrm{CH} ; 172.2 \mathrm{C}=0$ of amide; $138.1 \mathrm{C} 1$ of 2,6-dimethylphenyl ring; $129.7 \mathrm{C} 2$ and $\mathrm{C} 6$ of 2,6-dimethylphenyl ring; 129.2 C3 and C5 of 2,6-dimethylphenyl ring; $136 \mathrm{C} 1$ of pyridine ring; $121.3 \mathrm{C} 2$ of pyridine ring pyridine; $142.9 \mathrm{C} 3$ and $\mathrm{C} 5$ of pyridine ring; $148.2 \mathrm{C} 2$ of 1,2,4-triazole ring; $149 \mathrm{C} 5$ of 1,2,4-triazole ring; $128 \mathrm{C} 1$ of benzene ring; $132 \mathrm{C} 2$ and $\mathrm{C} 6$ of benzene ring; $118 \mathrm{C} 3$ and C5 of benzene ring; $168.4 \mathrm{C} 4$ of benzene ring; $35.5 \mathrm{SCH} 2 ; 25.6 \mathrm{CH} 3$ of 2,6 dimethyl phenyl. Mass (m/z): 459.02

\section{Antibacterial and antifungal activity}

The antibacterial activity was determined by the cup plate method. Microbial strains (ATCC No): Staphylococcus aureus (12598); Bacillus subtilis (6051); Pseudomonas aeruginosa (25619); Escherichia coli (25922) is used for the antibacterial activity. In this method sterilized molten nutrient agar media $(20 \mathrm{ml})$ was poured aseptically and spread on the sterilized petri dishes $(10 \mathrm{~cm})$. The bacterial culture (CFU-10 ${ }^{7-}$ $10^{9} / \mathrm{ml} ; 0.1 \mathrm{ml}$ ) was added to it and mixed by swirl motion and kept aside. After setting of the culture media, a sterilized glass tube $(5 \mathrm{~mm}$ diameter) was used aseptically to scoop out the media to make wells. Two drops $(0.1 \mathrm{ml})$ of the sample solution were transferred to these wells aseptically. These were then incubated at $37 \pm 1$. $\mathrm{C}$ for $24 \mathrm{~h}$. Control cups contained DMSO only. The experiments were carried out in triplicate. The result (mean value $n=3$ ) were recorded by measuring the zone of growth inhibition around the cups in $\mathrm{mm}$ at $100 \mu \mathrm{g} / \mathrm{ml}$ concentration and compared with standard drug norfloxacin. The statistical analysis was carried out using student t-test, and the \% of growth inhibition was calculated by taking norfloxacin as a positive control with $100 \%$ inhibitions for Gram+ve and Gram-ve bacteria. This same procedure adopted for antifungal activity. Fungal strain (ATCC No.) Aspergillus niger (9029); Candida albicans (2091); Aspergillus fumigates(36607) has been utilized for antifungal activity. The zone of inhibition (\% inhibition) and MIC for standard drug i.e. clotrimazole and for synthesized compounds were determined by using the same procedure as described under antibacterial screening.

\section{Anti-inflammatory activity}

All the synthesized compounds were screened for acute antiinflammatory activity by using carrageenan-induced rat paw edema model (Winter et al., 1962). Male albino rats of either sex weighing (170-220) g of either sex used. The animals were divided into four groups of six each. They were starvated overnight with water ad libitium prior to the day of the experiment. Control groups received 1 $\mathrm{ml}$ of $0.5 \%$ sodium carboxymethylcellulose (sodium CMC), the standard group received $20 \mathrm{mg} / \mathrm{kg}$ ibuprofen and test groups were received 100, $200 \mathrm{mg} / \mathrm{kg}$ of synthesized compounds orally. One hour later; a sub planar injection of $0.05 \mathrm{ml}$ of $1 \%$ solution of carrageenan in sterile distilled water was administered to the left hind footpad of each animal. The paw edema volume was measured with a digital plethysmometer at $0,1,2,3,4$, and $5 \mathrm{hr}$. after carrageenan injection. Paw edema volume was compared with vehicle control group and percent reduction was calculated as:

\section{$\%$ edema inhibition $=1-\mathrm{Vt} / \mathrm{Vc} \times 100$}

Where: Vt and Vc were oedema volume in the drug-treated and the control groups respectively. The results were expressed as percentage inhibition of edema over the untreated control group.

\section{RESULTS}

\section{Chemistry}

The Synthesis of the intermediate and target compounds was accomplished according to the steps depicted in the scheme of synthesis (fig. 2). Potassium dithiocarbazinate salt (2) was obtained from the reaction of isonicotinic acid hydrazides [1] with carbon disulfide in basic medium $(\mathrm{KOH})$ and converted into 4-amino-5-(pyridin-4-yl)-4H-1,2,4triazole-3-thiol [3] by the treatment with hydrazine hydrate. The synthesis of the other compounds was performed by the reaction of 2 with seven different benzaldehyde to form 4 [(substituted phenyl)methylene]-amino-5-(pyridine-4-yl)-4H-1,2,4-triazol-3-thiol [4]. The final compounds were synthesized by the reaction of 3 with four different acetanilide resulting in the formation of 4-[substituted phenyl)methylene]-amino-3-(N-substituted carboxamidomethylthio)-5(pyridine-4-yl)-4H-1,2,4-triazoles [5]. The elemental analysis data of synthesized compounds are given in table 1 . Synthesized compounds were characterized by IR, ${ }^{1} \mathrm{HNMR},{ }^{13} \mathrm{CNMR}$, LC-MS (FAB) and elemental analysis. All compounds were shown the solubility in DMSO, ethanol and acetonitrile and least in methanol and acetone.

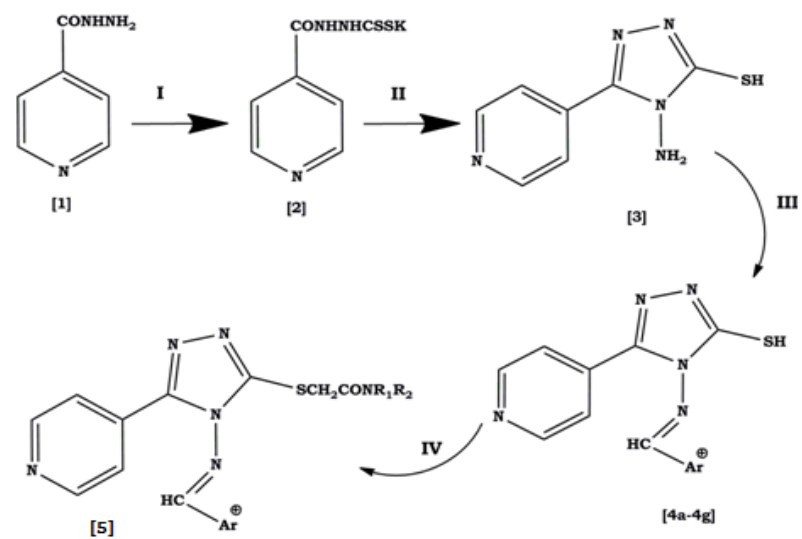

Fig. 2: Scheme for the synthesis; reagent and reaction condition: I) $\mathrm{CS}_{2}$, ethanolic $\mathrm{KOH}$, reflux $16 \mathrm{~h}$; II) $\mathrm{NH}_{2}-\mathrm{NH}_{2}$. $\mathrm{H}_{2} \mathrm{O}, \mathrm{reflux}, 4 \mathrm{~h}$; III) aromatic aldehyde, methanol, reflux, $3 \mathrm{~h}$; IV) acetanilide, Aq. $\mathrm{KOH}$, ethanol, $55^{\circ} \mathrm{C}$ 
Table 1: Elemental analysis of synthesized final compounds

\begin{tabular}{|c|c|c|c|c|c|}
\hline \multirow[t]{2}{*}{ Compound code } & \multirow[t]{2}{*}{ Molecular formula } & \multirow[t]{2}{*}{ Molecular weight } & \multicolumn{3}{|c|}{ Elemental analysis \% found (calculated) } \\
\hline & & & $\mathbf{C}$ & $\mathbf{H}$ & $\mathbf{N}$ \\
\hline $\mathrm{PJ}-\mathrm{A}_{1}$ & $\mathrm{C}_{24} \mathrm{H}_{22} \mathrm{~N}_{6} \mathrm{OS}$ & 442.54 & $65.14(65.13)$ & $5.01(5.02)$ & $18.99(18.98)$ \\
\hline $\mathrm{PJ}-\mathrm{A}_{2}$ & $\mathrm{C}_{24} \mathrm{H}_{21} \mathrm{ClN}_{6} \mathrm{OS}$ & 476.98 & $60.43(60.42)$ & $4.44(4.45)$ & $17.62(17.60)$ \\
\hline $\mathrm{PJ}-\mathrm{A}_{3}$ & $\mathrm{C}_{24} \mathrm{H}_{21} \mathrm{ClN}_{6} \mathrm{OS}$ & 476.98 & $60.43(60.42)$ & $4.44(4.45)$ & $17.62(17.60)$ \\
\hline $\mathrm{PJ}-\mathrm{A}_{4}$ & $\mathrm{C}_{24} \mathrm{H}_{21} \mathrm{ClN}_{6} \mathrm{OS}$ & 476.98 & $60.43(60.42)$ & $4.44(4.45)$ & $17.62(17.60)$ \\
\hline $\mathrm{PJ}-\mathrm{A}_{5}$ & $\mathrm{C}_{24} \mathrm{H}_{21} \mathrm{BrN}_{6} \mathrm{OS}$ & 521.43 & $55.28(55.27)$ & $4.06(4.05)$ & $16.12(16.13)$ \\
\hline $\mathrm{PJ}-\mathrm{A}_{6}$ & $\mathrm{C}_{24} \mathrm{H}_{21} \mathrm{BrN}_{6} \mathrm{OS}$ & 521.43 & $55.28(55.27)$ & $4.06(4.05)$ & $16.12(16.13)$ \\
\hline $\mathrm{PJ}-\mathrm{A}_{7}$ & $\mathrm{C}_{25} \mathrm{H}_{24} \mathrm{~N}_{6} \mathrm{OS}$ & 456.56 & $65.77(65.78)$ & $5.30(5.29)$ & $18.41(18.40)$ \\
\hline $\mathrm{PJ}-\mathrm{A}_{8}$ & $\mathrm{C}_{25} \mathrm{H}_{24} \mathrm{~N}_{6} \mathrm{O}_{2} \mathrm{~S}$ & 472.56 & $63.54(63.52)$ & $5.12(5.13)$ & $17.78(17.79)$ \\
\hline PJ-A9 & $\mathrm{C}_{24} \mathrm{H}_{20} \mathrm{Cl}_{2} \mathrm{~N}_{6} \mathrm{OS}$ & 511.43 & $56.63(56.65)$ & $3.94(3.93)$ & $16.43(16.42)$ \\
\hline $\mathrm{PJ}-\mathrm{A}_{10}$ & $\mathrm{C}_{24} \mathrm{H}_{21} \mathrm{Cl}_{2} \mathrm{~N}_{6} \mathrm{OS}$ & 511.43 & $56.63(56.65)$ & $3.94(3.93)$ & $16.43(16.42)$ \\
\hline $\mathrm{PJ}-\mathrm{A}_{11}$ & $\mathrm{C}_{26} \mathrm{H}_{28} \mathrm{~N}_{7} \mathrm{OS}$ & 486.0 & $64.31(64.32)$ & $5.60(5.62)$ & 20.19 (20.18) \\
\hline $\mathrm{PJ}-\mathrm{A}_{12}$ & $\mathrm{C}_{24} \mathrm{H}_{22} \mathrm{FN}_{6} \mathrm{OS}$ & 460.53 & $62.59(62.60)$ & $4.60(4.62)$ & $18.25(18.20)$ \\
\hline $\mathrm{PJ}-\mathrm{A}_{13}$ & $\mathrm{C}_{24} \mathrm{H}_{23} \mathrm{~N}_{6} \mathrm{O}_{2} \mathrm{~S}$ & 459.00 & $62.86(62.88)$ & $4.84(4.85)$ & $18.33(18.32)$ \\
\hline
\end{tabular}

\section{Antibacterial activity}

Among all compounds, compound no. PJ-A4, PJ-A7 and PJ-A13 shows more than $90 \%$ of zone of inhibition against both Gram positive and Gram negative organisms and PJ-A6, PJ-A9, A10 and A11 shows more than $80 \%$ of zone of inhibition against both Gram positive and Gram negative organisms and remaining compounds shows more than $50 \%$ and less than $70 \%$ of zone of inhibition against both Gram positive and Gram negative organisms. Among all these compounds only A13, shows excellent MIC against both Gram positive and Gram negative organisms compare to standard Norflaxacin. Data of antibacterial acivity is shown in table 2 .

\section{Antifungal activity}

Among all compounds, compound no. PJ-A4, A7, A9, A11 and A13 shows more than $90 \%$ of zone of inhibition, A2, A10 and A12 shows more than $80 \%$ of zone of inhibition and rest of compounds shows more than $50 \%$ and less than $70 \%$ of inhibition against all organisms. Among all these compounds only A13, shows excellent MIC against all fungal strains compare to standard norflaxacin. Data of antifungal activity shown in table 3 .

Table 2: Antibacterial activity of synthesized compound at $100 \mu \mathrm{g} / \mathrm{ml}$

\begin{tabular}{|c|c|c|c|c|c|c|c|c|c|}
\hline \multirow[t]{2}{*}{$\begin{array}{l}\text { S. } \\
\text { No. }\end{array}$} & \multirow[t]{2}{*}{$\begin{array}{l}\text { Code } \\
\text { No. }\end{array}$} & \multicolumn{2}{|c|}{$\begin{array}{l}\text { S. aureus } \\
\text { (ATCC-12598) }\end{array}$} & \multicolumn{2}{|l|}{$\begin{array}{l}\text { B. subtilis } \\
\text { (ATCC-6051) }\end{array}$} & \multicolumn{2}{|c|}{$\begin{array}{l}\text { P. aeruginosa } \\
\text { (ATCC-25619) }\end{array}$} & \multicolumn{2}{|c|}{$\begin{array}{l}\text { E. coli } \\
\text { (MTCC-25922) }\end{array}$} \\
\hline & & $\begin{array}{l}\text { In mm } \\
\text { mean }\end{array}$ & $\begin{array}{l}\text { \% of } \\
\text { inhibition }\end{array}$ & In mm mean & $\begin{array}{l}\text { \% of } \\
\text { inhibition }\end{array}$ & In mm mean & $\begin{array}{l}\text { \% of } \\
\text { inhibition }\end{array}$ & In mm mean & $\begin{array}{l}\text { \% of } \\
\text { inhibition }\end{array}$ \\
\hline 1. & $\mathrm{PJ}-\mathrm{A}_{1}$ & $14.00 \pm 2.0$ & 48.85 & $16.66 \pm 1.15$ & 56.15 & $15.33 \pm 2.51$ & 55.6 & $14.33 \pm 1.15$ & 53.08 \\
\hline 2. & $\mathrm{PJ}-\mathrm{A}_{2}$ & $25.00 \pm 2.0$ & 78.4 & $24.66 \pm 1.52$ & 82.00 & $23.00 \pm 2.64$ & 85.0 & $24.33 \pm 1.52$ & 92.1 \\
\hline 3. & $\mathrm{PJ}-\mathrm{A}_{3}$ & $18.33 \pm 1.1$ & 63.90 & $19.33 \pm 1.15$ & 67.3 & $22.66 \pm 1.15$ & 81.5 & $23.66 \pm 2.30$ & 88.4 \\
\hline 4. & $\mathrm{PJ}-\mathrm{A}_{4}$ & $27.33 \pm 2.5$ & 95.45 & $28.00 \pm 1.73$ & 91.6 & $25.33 \pm 0.57$ & 91.77 & $25.33 \pm 2.08$ & 96.19 \\
\hline 5. & $\mathrm{PJ}-\mathrm{A}_{5}$ & $22.00 \pm 3.4$ & 66.2 & $23.00 \pm 2.00$ & 77.14 & $20.00 \pm 2.64$ & 72.4 & $23.00 \pm 3.21$ & 87.35 \\
\hline 6. & $\mathrm{PJ}-\mathrm{A}_{6}$ & $25.66 \pm 0.5$ & 89.00 & $26.66 \pm 2.08$ & 89.65 & $24.33 \pm 1.53$ & 87.0 & $23.33 \pm 0.57$ & 53.1 \\
\hline 7. & $\mathrm{PJ}-\mathrm{A}_{7}$ & $26.33 \pm 2.5$ & 92.0 & $19.66 \pm 2.08$ & 65.0 & $19.66 \pm 0.57$ & 70.7 & $20.00 \pm 3.51$ & 88.03 \\
\hline 8. & $\mathrm{PJ}-\mathrm{A}_{8}$ & $16.66 \pm 2.3$ & 55.00 & $18.33 \pm 2.08$ & 62.8 & $20.33 \pm 2.08$ & 74.0 & $18.66 \pm 1.52$ & 70.4 \\
\hline 9. & $\mathrm{PJ}-\mathrm{A}_{9}$ & $25.33 \pm 2.0$ & 88.38 & $26.00 \pm 2.64$ & 89.6 & $24.66 \pm 1.52$ & 88.87 & $23.66 \pm 2.30$ & 89.8 \\
\hline 10. & $\mathrm{PJ}-\mathrm{A}_{10}$ & $24.33 \pm 2.8$ & 84.89 & $25.00 \pm 1.00$ & 84.26 & $23.33 \pm 1.15$ & 84.37 & $22.66 \pm 1.52$ & 86.8 \\
\hline 11. & $\mathrm{PJ}-\mathrm{A}_{11}$ & $23.00 \pm 1.9$ & 82.74 . & $24.66 \pm 2.08$ & 82.4 & $22.33 \pm 2.08$ & 80.2 & $21.66 \pm 2.51$ & 82.27 \\
\hline 12. & $\mathrm{PJ}-\mathrm{A}_{12}$ & $19.33 \pm 2.3$ & 67.44 & $20.66 \pm 1.52$ & 68.0 & $18.66 \pm 0.57$ & 65.6 & $19.66 \pm 2.51$ & 74.4 \\
\hline 13. & $\mathrm{PJ}-\mathrm{A}_{13}$ & $26.66 \pm 1.5$ & 92.87 & $27.33 \pm 1.52$ & 94.8 & $26.00 \pm 3.00$ & 94.2 & $25.33 \pm 2.88$ & 96.15 \\
\hline \multicolumn{2}{|c|}{ Norfloxacin } & $28.6 \pm 1.1$ & 100.0 & $29.67 \pm 1.15$ & 100.0 & $27.66 \pm 1.15$ & 100.0 & $26.33 \pm 0.57$ & 100.0 \\
\hline \multicolumn{2}{|c|}{ DMSO } & $8.33 \pm 1.15$ & 10.3 & $8.33 \pm 0.57$ & 14.1 & $7.33 \pm 1.00$ & 10.3 & $8.00 \pm 1.00$ & 14.1 \\
\hline
\end{tabular}

Table 3: Minimum inhibitory concentration of some selected compounds (antibacterial activity)

\begin{tabular}{llllll}
\hline S. No. & Code No. & MIC in $\mu \mathrm{g} / \mathbf{m l}$ & & \\
\cline { 3 - 6 } & & S. aureus (ATCC-12598) & $\begin{array}{l}\text { B. subtilis } \\
\text { (ATCC-6051) }\end{array}$ & P. aeruginosa (ATCC-25619) & $\begin{array}{l}\text { E. coli. } \\
\text { (MTCC-25922) }\end{array}$ \\
\hline 1. & ${\mathrm{PJ}-A_{4}}_{2 .}$ & 5 & 7 & 11 & 9 \\
2. & $\mathrm{PJ}_{7}$ & 6 & 7 & 11 & 9 \\
3. & $\mathrm{PJ}_{11}$ & 7 & 8 & 13 & 10 \\
4. & $\mathrm{PJ}_{12}$ & 6 & 7 & 12 & 11 \\
5. & $\mathrm{PJ}_{13}$ & 4 & 6 & 10 & 8 \\
Norfloxacin & - & 4 & 6 & 10 & 8 \\
\hline
\end{tabular}

\section{Anti-inflammatory activity}

Among all the synthesized compounds, compound no. PJ-A4, PJ-A8, PJ-A9 and PJ-A13 showed significant anti-inflammatory activity 70 to $76 \%$ of paw edema inhibition compare to standard drug
Ibuprofen which shows $83.3 \%$ after 5 h. Remaining compounds showed moderate to weak anti-inflammatory activity. The antiinflammatory activity of these compounds attributed to the inhibition of cyclooxygenase enzyme which plays vital role in the inflammation process. 
Table 4: Antifungal activity of the synthesized compounds at $100 \mu \mathrm{g} / \mathrm{ml}$

\begin{tabular}{|c|c|c|c|c|c|c|c|}
\hline \multirow[t]{3}{*}{ S. No. } & \multirow[t]{3}{*}{ Code No. } & \multicolumn{6}{|c|}{ Zone of inhibition at concentration $(20 \mu \mathrm{g} / \mathrm{ml})$} \\
\hline & & \multicolumn{2}{|c|}{$\begin{array}{l}\text { Aspergillus niger } \\
\text { MTCC-1344 }\end{array}$} & \multicolumn{2}{|c|}{$\begin{array}{l}\text { Candida Albicans } \\
\text { MTCC-227 }\end{array}$} & \multicolumn{2}{|c|}{$\begin{array}{l}\text { Fusarium oxysporum } \\
\text { MTCC-129 }\end{array}$} \\
\hline & & In mm mean & \% of Inhibition & In mm mean & \% of Inhibition & In mm mean & \% of Inhibition \\
\hline 1. & $\mathrm{PJ}-\mathrm{A}_{1}$ & $12.00 \pm 1.0$ & 54.45 & $13.33 \pm 3.0$ & 56.52 & $11.00 \pm 3.0$ & 50.92 \\
\hline 2. & $\mathrm{PJ}-\mathrm{A}_{2}$ & $18.66 \pm 1.5$ & 84.48 & $20.66 \pm 3.7$ & 88.66 & $18.66 \pm 1.1$ & 85.71 \\
\hline 3. & $\mathrm{PJ}-\mathrm{A}_{3}$ & $17.33 \pm 2.0$ & 78.77 & $18.33 \pm 0.5$ & 78.26 & $16.33 \pm 1.5$ & 75.46 \\
\hline 4. & $\mathrm{PJ}-\mathrm{A}_{4}$ & $20.66 \pm 1.5$ & 93.6 & $22.33 \pm 4.5$ & 96.65 & $21.00 \pm 2.0$ & 96.95 \\
\hline 5. & $\mathrm{PJ}-\mathrm{A}_{5}$ & $15.33 \pm 0.5$ & 69.6 & $16.66 \pm 2.5$ & 71.50 & $15.00 \pm 2.6$ & 69.4 \\
\hline 6. & $\mathrm{PJ}-\mathrm{A}_{6}$ & $14.00 \pm 1.5$ & 63.3 & $15.33 \pm 2.8$ & 65.21 & $14.66 \pm 3.0$ & 66.66 \\
\hline 7. & $\mathrm{PJ}-\mathrm{A}_{7}$ & $20.66 \pm 1.0$ & 93.8 & $22.00 \pm 1.0$ & 95.56 & $20.33 \pm 1.0$ & 93.98 \\
\hline 8. & $\mathrm{PJ}-\mathrm{A}_{8}$ & $12.00 \pm 3.0$ & 54.0 & $12.00 \pm 5.0$ & 51.0 & $11.66 \pm 1.5$ & 53.70 \\
\hline 9. & $\mathrm{PJ}-\mathrm{A}_{9}$ & $21.00 \pm 2.0$ & 95.48 & $22.33 \pm 1.5$ & 95.65 & $20.66 \pm 1.1$ & 95.23 \\
\hline 10. & $\mathrm{PJ}-\mathrm{A}_{10}$ & $18.33 \pm 3.0$ & 83.8 & $20.66 \pm 1.6$ & 88.66 & $17.33 \pm 1.5$ & 80.23 \\
\hline 11. & $\mathrm{PJ}-\mathrm{A}_{11}$ & $20.33 \pm 2.5$ & 92.40 & $21.66 \pm 2.0$ & 92.70 & $20.00 \pm 2.6$ & 92.59 \\
\hline 12. & $\mathrm{PJ}-\mathrm{A}_{12}$ & $19.00 \pm 3.0$ & 86.30 & $20.33 \pm 1.1$ & 86.95 & $18.66 \pm 2.5$ & 85.71 \\
\hline \multirow[t]{3}{*}{13.} & $\mathrm{PJ}-\mathrm{A}_{13}$ & $20.66 \pm 2.3$ & 93.63 & $21.66 \pm 0.5$ & 92.96 & $20.66 \pm 2.5$ & 95.3 \\
\hline & Clotrimazole & $22.00 \pm 1.0$ & 100.0 & $23.3 \pm 0.57$ & 100.0 & $21.66 \pm 2.082$ & 100.0 \\
\hline & DMSO & $8.0 \pm 1.0$ & 18.8 & $7.66 \pm 0.58$ & 16.3 & $8.33 \pm 0.57$ & 21.3 \\
\hline
\end{tabular}

Table 5: Minimum inhibitory concentration of some selected compounds (antifungal activity)

\begin{tabular}{|c|c|c|c|c|}
\hline \multirow[t]{2}{*}{ S. No. } & \multirow[t]{2}{*}{ Code No. } & \multicolumn{3}{|l|}{ MIC in $\mu \mathrm{g} / \mathrm{ml}$} \\
\hline & & A. nigers (MTCC-1344) & C. albican (MTCC-227) & F. oxysporum (MTCC-129) \\
\hline 1 & $\mathrm{PJ}-\mathrm{A}_{4}$ & 13 & 7 & 11 \\
\hline 2 & $\mathrm{PJ}-\mathrm{A}_{7}$ & 13 & 7.5 & 12 \\
\hline 3 & $\mathrm{PJ}-\mathrm{A}_{9}$ & 13 & 8 & 12 \\
\hline 4 & $\mathrm{PJ}-\mathrm{A}_{11}$ & 14 & 8 & 12 \\
\hline 5 & $\mathrm{PJ}-\mathrm{A}_{12}$ & 6 & 7 & 12 \\
\hline 6 & $\mathrm{PJ}-\mathrm{A}_{13}$ & 12 & 6 & 10 \\
\hline Clotrimazole & - & 12 & 6 & 10 \\
\hline
\end{tabular}

Table 6: Anti-inflammatory activity of synthesized final compounds

\begin{tabular}{|c|c|c|c|c|}
\hline \multirow[t]{2}{*}{ Compound code } & \multicolumn{2}{|c|}{$\begin{array}{l}\text { Change in paw odema volume after treatment in } \mathrm{ml}( \pm \\
\text { SEM) }\end{array}$} & \multicolumn{2}{|c|}{$\begin{array}{l}\text { Percentage inhibition of odema after } \\
\text { treatment }\end{array}$} \\
\hline & $3 \mathbf{h}$ & $5 \mathbf{h h}$ & $3 \mathbf{h}$ & $5 \mathbf{h}$ \\
\hline $\begin{array}{l}\text { Solvent control }(0.5 \% \text { CMC })(1 \\
\mathrm{ml} / \mathrm{kg})\end{array}$ & $0.60 \pm 0.03$ & $0.62 \pm 0.03$ & - & - \\
\hline Ibuprofen (20 mg/kg) b. o & $0.14 \pm 0.03$ & $0.10 \pm 0.03$ & 76.6 & 83.3 \\
\hline $\mathrm{PJ}-\mathrm{A}_{1}(100 \mathrm{mg} / \mathrm{kg})$ & $0.42 \pm 0.02$ & $0.40 \pm 0.03$ & 30.0 & 33.33 \\
\hline$(200 \mathrm{mg} / \mathrm{kg})$ & $0.38 \pm 0.02$ & $0.36 \pm 0.04$ & 36.6 & 40.0 \\
\hline $\mathrm{PJ}-\mathrm{A}_{2} 100 \mathrm{mg} / \mathrm{kg} \mathrm{p}, \mathrm{o}$ & $0.26 \pm 0.04$ & $0.24 \pm 0.03$ & 56.66 & 60.0 \\
\hline $200 \mathrm{mg} / \mathrm{kg}$ p,o & $0.21 \pm 0.03$ & $0.18 \pm 0.04$ & 65.0 & 70.0 \\
\hline PJ-A $100 \mathrm{mg} / \mathrm{kg}$ p,o & $0.29 \pm 0.02$ & $0.28 \pm 0.04$ & $0.29 \pm 0.04$ & $0.28 \pm 0.02$ \\
\hline $200 \mathrm{mg} / \mathrm{kg}$ p,o & $0.26 \pm 0.02$ & $0.23 \pm 002$ & 51.66 & 53.33 \\
\hline $\mathrm{PJ}^{-\mathrm{A}_{4}} 100 \mathrm{mg} / \mathrm{kg} \mathrm{p}, \mathrm{o}$ & $0.20 \pm 0.02$ & $0.17 \pm 0.03$ & 66.66 & 71.6 \\
\hline $200 \mathrm{mg} / \mathrm{kg} \mathrm{p,o}$ & $0.18 \pm 0.02$ & $0.15 \pm 002$ & 70.0 & 75.0 \\
\hline PJ-As $100 \mathrm{mg} / \mathrm{kg} \mathrm{p,o}$ & $0.32 \pm 0.05$ & $0.30 \pm 0.03$ & 46.6 & 50.0 \\
\hline $200 \mathrm{mg} / \mathrm{kg} \mathrm{p,o}$ & $0.29 \pm 0.05$ & $0.26 \pm 0.04$ & 51.6 & 56.6 \\
\hline PJ-A $6100 \mathrm{mg} / \mathrm{kg} \mathrm{p,o}$ & $0.36 \pm 0.02$ & $0.30 \pm 0.03$ & 40.0 & 45.0 \\
\hline 200 mg/kg p,o & $0.32 \pm 0.05$ & $0.30 \pm 0.03$ & 46.6 & 50.0 \\
\hline $\mathrm{PJ}^{-\mathrm{A}_{7}} 100 \mathrm{mg} / \mathrm{kg} \mathrm{p}, \mathrm{o}$ & $0.24 \pm 1.0 .04$ & $0.21 \pm 0.05$ & 60.0 & 65.0 \\
\hline $200 \mathrm{mg} / \mathrm{kg} \mathrm{p,o}$ & $0.21 \pm 0.03$ & $0.18 \pm 0.04$ & 65.0 & 70.0 \\
\hline PJ-A $100 \mathrm{mg} / \mathrm{kg} \mathrm{p,o}$ & $0.24 \pm 1.0 .04$ & $0.21 \pm 0.05$ & 60.0 & 65.0 \\
\hline $200 \mathrm{mg} / \mathrm{kg}$ p,o & $0.21 \pm 0.03$ & $0.18 \pm 0.04$ & 65.0 & 70.0 \\
\hline PJ-A $9100 \mathrm{mg} / \mathrm{kg}$ p,o & $0.21 \pm 0.03$ & $0.18 \pm 0.04$ & 65.0 & 70.0 \\
\hline 200 mg/kg p,o & $0.18 \pm 0.02$ & $0.15 \pm 002$ & 70.0 & 75.0 \\
\hline $\mathrm{PJ}-\mathrm{A}_{10} 100 \mathrm{mg} / \mathrm{kg} \mathrm{p,o}$ & $0.32 \pm 0.05$ & $0.30 \pm 0.03$ & 46.6 & 50.0 \\
\hline $200 \mathrm{mg} / \mathrm{kg} \mathrm{p,o}$ & $0.26 \pm 0.02$ & $0.23 \pm 002$ & 56.6 & 61.6 \\
\hline $\mathrm{PJ}-\mathrm{A}_{11} 100 \mathrm{mg} / \mathrm{kg} \mathrm{p,o}$ & $0.35 \pm 0.02$ & $0.33 \pm 0.03$ & 41.6 & 45.0 \\
\hline $200 \mathrm{mg} / \mathrm{kg} \mathrm{p,o}$ & $0.32 \pm 0.05$ & $0.30 \pm 0.03$ & 46.6 & 50.0 \\
\hline PJ-A 12100 mg/kg p,o & $0.29 \pm 0.05$ & $0.26 \pm 0.04$ & 51.6 & 56.6 \\
\hline 200 mg/kg p,o & $0.26 \pm 0.02$ & $0.23 \pm 002$ & 56.6 & 61.6 \\
\hline $\mathrm{PJ}-\mathrm{A}_{13} 100 \mathrm{mg} / \mathrm{kg} \mathrm{p,o}$ & $0.21 \pm 0.03$ & $0.18 \pm 0.04$ & 65.0 & 70.0 \\
\hline $200 \mathrm{mg} / \mathrm{kg} \mathrm{p}, \mathrm{o}$ & $0.18 \pm 0.04$ & $0.14 \pm 2.3$ & 70.0 & 76.6 \\
\hline
\end{tabular}

*Values are mean \pm SEM; No of animals in each group are $(n=6) ;{ }^{*}$ value $<0.05$ 


\section{DISCUSSION}

\section{Antibacterial activity}

The data revealed that $p$-chloro and $m$-hydroxy substituted compounds shows excellent activity against all tested organisms. The presence of an electron withdrawing group such as chloro in para position enhances the liphophilicity of the molecule enabling it to penetrate the microbial cell more easily and shows the good activity. The presence of $\mathrm{OH}$ group on aromatic ring increases the hydrogen bonding of the compound with bacterial cell wall proteins containing free $\mathrm{SH}$ group and therefore it shows good activity. Un-substituted and methoxy substituted compounds shows the least activity.

\section{Antifungal activity}

The data revels that p-chloro and o-hydroxy substituted compounds show excellent activity against all tested organisms. The presence of electron withdrawing group such as chloro in para position enhances the lipophilicity of the molecule enabling it to penetrate the microbial cell more easily and shows the minimum inhibitory concentration compare to standard clotrimazole and almost equal to standard. The presence of $\mathrm{OH}$ group on aromatic ring increases the hydrogen bonding of the compound with fungal cell wall proteins containg free SH group and therefore it shows good activity. Unsubstituted and methoxy substituted compounds shows the least activity. Electron withdrawing group in meta position shows less MIC compare to standard.

\section{Anti-inflammatory activity}

4-chloro, 2,4-dichloro, 2,6-dichloro and hydroxyl substituted on benzyledene moiety shows high degree of anti-inflammatory activity. It may be because of the presence of trifluoromethyl along with nitro group in para-position of benzene ring which is present on $3^{\text {rd }}$ position of triazole moiety. Presence of electron withdrawing groups like chloro in para position in benzelidine ring shows more activity compare to at ortho and meta position. presence of two chlorine group at ortho and para position ie 2,4-dichloro shows more activity. Unsusbstituted benzelidine ring and presence of electron donating group on benzelidine ring of triazole moiety such as methoxy group shows decreases in activity. Compounds with bulkier substitution such as nitro in para position along with trifluoro methyl group on phenyl ring 3rd position of triazole moiety showed good activity. Compounds having high molecular weight showed more activity

\section{CONCLUSION}

The isoniazid based 1,2,4-triazoles derivatives has been synthesized and spectral analysis data denoted that the compound is synthesized as they design. All these synthesized compound evaluated for the antibacterial, antifungal and anti-inflammatory activity and shown potential candidate for treating diseases. Isoniazid based 1,2,4 triazole derivatives has shown good antibacterial, antifungal and anti-inflammatory activity.

\section{ACKNOWLEDGEMENT}

One of the author wish to acknowledge SAIF, Punjab University, Chandigarh for IR, ${ }^{1} \mathrm{H}-\mathrm{NMR},{ }^{13} \mathrm{C}-\mathrm{NMR}$ and for Mass spectra. We also thankful to Himedia, Bioscience Company for providing microbial strain.

\section{AUTHORS CONTRIBUTIONS}

All the author have contributed equally

\section{CONFLICT OF INTERESTS}

\section{Declared none}

\section{REFERENCES}

1. Ajaykumar J, Vikash Kumar M, Varsha K. Synthesis and antimicrobial activity some new 1,2,4-triazoles. Asian J Chem 2017;29:1317-22.

2. Ajaykumar, Varsha K, Amit V, Sushil KK, Prashant S, Vikash KM. Synthesis, characterization and Antimycobaterial activity of some newer 1,2,4-triazole derivatives. Int J Pharm Bio Res 2015;5:37992.

3. Gajanan S, Sandyavalli MS, Manjunath E, Kavitha NV. Synthesis and anti-inflammatory activity of 3,5-Diphenyl 4-amino 1,2,4triazole derivatives. World J Pharm Res 2017;6:1744-54.

4. Godhani DR, Jogel AA, Sanghani AM, Mehta JP. Synthesis and biological screening of 1,2,4-triazole derivatives. Indian J Chem 2015;54B:556-64.

5. Hany MD, Khaled E, Ali ZS, Ammed AS. Synthesis and biological activities of some new spiro 1,2,4-triazole derivatives having sulfonamide moiety. Org Communications 2017;10:280-7.

6. Hasan MJ, Adnan IM, Abass SJ. Antibacterial activity importance of 1, 2, 3-triazole and 1, 2, 4-triazoleby click chemistry. J Chem Chem Sci 2015;5:317-24.

7. Ledeti I, Bercean V, Alexa A, Foica C, Futa LM, Dehelean C, et al Preparation and antibacterial properties of substituted 1,2,4triazoles. J Chem 2015;5:87-93.

8. Mehdi K, Mahboobeh S, Iraj N, Seyedeh RB. Synthesis, characterization and antibacterial activity of some novel thiosemicarbazides, 1,2,4-triazol-3-thiols and their $s$ substituted derivatives. Iranian J Pharm Res 2015;14:67-75.

9. Yasemin U, Sadik D, Fatih C, Zeynep A, Murat K, Kemal. Synthesis of new 1,2,4-triazole compounds containing schiff and mannich bases (morpholine) with antioxidant and antimicrobial activities. J Enzyme Inhibition Med Chem 2016;31:89-95.

10. Yasmin K, Mohammad, Vijender S, Mohammad S. Synthesis, characterization and anticonvulsant activity of some novel 4, 5disubstituted-1, 2, 4-triazole derivatives. J Appl Pharm Sci 2017;7:158-67.

11. Noha RM, Sh El-Etrwy. A design, synthesis and biological evaluation of some 1,2,4-triazole derivatives based on Schiff's base bearing Benzimdazole moiety. Asian J Pharm Anal Med Chem 2015;3:62-75.

12. Mohammad A. Study of some 1,2,4-triazole derivatives and their biological activities. Int J Pharm Drug Anal 2015;2:325-8.

13. Li Jung M, Yan Xia S, Hong Ke WS, Xing Hai L, Yong Gang Z. Microwave assisted synthesis and antifungal activity of some novel thioethers containing 1,2,4-triazole moiety. Appl Sci 2015;5:1211-20.

14. Rakesh KM, Birendra SY, Rai AK. Synthesis, characterization and biological evaluation of novel 1,2,4-triazole derivatives as potent antibacterial and anti-inflammatory agents. Der Pharm Chem 2014;6:137-43. 